\title{
HISTORICAL STUDIES OF CHRISTIAN EDUCATION AND ITS IMPLEMENTATION IN THE INDUSTRIAL REVOLUTION 4.0
}

\author{
Kasiatin Widianto \\ Evangelical Theological Seminary of Indonesia - Surabaya \\ E-mail: kasiatinwidianto@sttii-surabaya.ac.id
}

\begin{abstract}
The term 'double predestination' simply means that, just as God predestines some, but Education is something that is very important for human life, and this is a divine mandate. This study aims to determine the pattern of Christian education from time to time and its implementation in the Industrial Revolution 4.0 era. This study uses a qualitative method with a literature study approach by reading, observing and analyzing literature sources on Christian education from time to time and its implementation in the Industrial Revolution Era 4.0. The results show that the situations and conditions behind the presence of education differ from time to time, but the similarity is that God has appointed certain people as agents of education. Where the patterns that are applied are harmonized with the surrounding conditions.
\end{abstract}

Keywords: Historically, Christian Education, Industrial Revolution 4.0.

\section{INTRODUCTION}

Education is very important in human life, because in essence education is a process of forming human behavior intellectually to master science, emotionally to control oneself and morally as a deepening and appreciation of cultural values that grow and develop in society. Education is a continuous and eternal process.[1] This is in line with John Dewey's statement which asserts that the educational process has no end.[2] This also applies to Christian education, that its

implementation is valid for a lifetime to help them to be entrusted to God's care, according to Bochlke.[3] Where parents and the church are the implementers.[4] Christian education is one of the duties and responsibilities of the church, because it is part of the Great Commission of Jesus (Matt. 28:19-20). The Great Commission is not only great but the greatest commission in history.[5] It is said to be great if it is 
based on who the person giving this mandate is and it is said to be great considering the magnitude of this mandate.[6] The Great Commission is a very important point in Christianity. This is evidenced by all the Bibles that tells of this subject (Matthew 28:16-20, Mark 16:1518, Luke 24:44-49, John 20:19-23; 21:1529, even Acts 1:6-8). The Great Commission is God's longing and heart for this world.[7] Therefore, Christian education must be carried out as if it is absorbed in a legitimate church task, so it must be carried out jointly and by all members of the congregation.[8] This ministry should not be neglected by the church.

A church without a Christian education is not a healthy church.[9] Campbell Wykoff states that the goal of Christian education is to make everyone aware of God and His love.[10] In fact, Martin Luther emphasized that the purpose of Christian education is so that a person is aware of his sins.[11]

With regard to education, the focus of this research is the pattern of Christian education from time to time and its implementation in the Industrial Revolution 4.0 era. This is important because we are currently in the industrial revolution 4.0 which is triggered by the development of information and communication technology. This undeniable reality has proven to have an impact on various fields of life, including Christian religious education. The Church has the duty to declare her function of proclaiming the Gospel to the whole world and teaching her people about the teachings of Christ.[12]

The problem formulation of this research is how is the pattern of Christian education from time to time and its implementation in the Industrial Revolution 4.0 Era? The goal is to find a pattern of Christian education that is applied from time to time and its implementation in the industrial era 4.0.

\section{RESEARCH METHODS}

In this study, the author uses a qualitative method with a literature study approach by reading, observing and analyzing literary sources about the pattern of Christian education from time to time and its implementation in the Industrial Revolution 4.0 Era.

\section{RESULTS AND DISCUSSION}

There is an ancient proverb that says 'Different fields of grasshoppers, different depths of fish' means that each region has different customs; one rule in one area can 
be different from the rules in another. The meaning contained in this proverb is a common and a reality in general. But in the world of Christian education this is not entirely the case, there are even differences. Especially in terms of the pattern of implementation. Based on various literature searches that have been carried out, the results are as follows.

First, there are different patterns applied in the implementation of Christian education from time to time, both during the Old Testament, New Testament, and during the church fathers, of course also in the era of the industrial revolution 4.0. Second, in the midst of the different patterns applied in each of these eras, there are also similarities in providing education, namely with a dialogical approach between educators and students.

The presence of the Industrial Revolution 4.0 era is a challenge but also brings many positive opportunities[13] for the continuity of Christian education. Sophisticated information technology that changes various aspects of human life can be an effective and efficient means for Christian education which must be managed with creative patterns in order to convey the 'educational mandate' properly and relevantly.

Religious Education in the Old Testament Education in the Old Testament era which is also known as Jewish Education is something very important in the process of Christian Religious Education. This is because there is a common thread between education in the Old Testament Era and the pattern and practice of Christian Religious Education to date. The Old Age Education had a great contribution to Christian Religious Education, one of which was the practice of God-centered education. This is one of the most beautiful inheritances.[14]

Since and after the exile the Israelites were active and diligent in learning[15] where Allah is considered the main teacher, who entrusts the task of religious education to prophets, priests, poets and wise men[16] whom Robert W. Pazmino calls the agent of Old Testament education.[17] where in general only boys became his disciples and received various teaching materials, namely the election of Abram, the creation of the heavens and the earth, the liberation from Egypt, the Law, the occupation of the promised land, the beginning the kingdom and the prophet's testimony about the tendency of the people of Israel to deviate and rebel against God; which, in general, the memorization method is the focus.[18]

The theological basis of Jewish religious education is first of all God's call to Abram, where the basis of His election 
was not because of the results of Abram's and his family's actions but because of His grace.[19] Based on this personal call, the Jewish leaders concluded that each new generation needed to be introduced to its heritage. The Jews in general and every family, especially the father, were assigned to pass on the riches of the Jewish faith to each new generation. That belief is evident in Deuteronomy 6:4-9, which is nothing but an educational mandate mandated to parents to teach their children. Where the ultimate goal is to instill God's love which is expressed through faithfulness and obedience.[20]

In Jewish society, the family is the most important and decisive educational institution. During the Babylonian exile, the family was the first and foremost center of education and the transmission of Jewish traditions for their children. They are also the first teachers for their children. To fulfill the expected educational requirements, parents are required to be lifelong students.[21] Where they must love God with all their heart, soul and strength, then pass it on to their children from generation to generation.

The character and pattern of Jewish education is different from other education systems. Flavius Josephus, the first century Jewish historian stated "our primary concern is the education of our children; and we think, this education is the most important business in all life to obey the laws given to us, and keep all the rules of wrong that have been passed down to us."[22]

Torah, as a source of Jewish education, is studied as a legal text that provides guidance and direction on how to build an ethical and religious life properly. Although Jewish education was centered on the law, this does not mean that they denied other knowledge. Instead, they accept and study it, in relation to the law. For example, in the study of the law on halal and haram food. The method of basic education in the family is quite simple. In addition to teaching reading and writing, parents teach by telling stories. They tell stories of important figures and events in the history of their nation. This serves to evoke a sense of patriotism in the child. Since childhood, children are accustomed to studying and memorizing the texts of the Bible.

Several stages of Jewish education. After basic education in the family, the second stage of basic education is calledBeit-Safar (The Hebrew; Book House), is intended for boys aged 5-10 years. This education generally takes place in the synagogue. Under the guidance of a scribe or rabbi, for the next five years, they 
were required to memorize the entire Torah. The next stage of Jewish education is calledBeit Talmud (Study House) which is intended for boys aged 10-14 years. In this education, they memorize the Torah and the prophets and other books. At the age of 14, they are expected to memorize the entire Tanakh (Hebrew Bible). Education in the Beit Talmud is an important stage in the education of Jewish boys because at this time they learn rhetoric, or the art of debating.

The next stage of education, those who are best in education at the BeitTalmud, are allowed to continue their studies at Beit Midrash (Study House). Education at this stage lasts at least 14 years. His main goal was to become a scribe.

\section{Religious Education in the New Testament}

If the religious education of the Jewish era, God was the center, then religious education in the New Testament was focused on Jesus, the Great Teacher. [23] Jesus was a charismatic teacher, emphasized Perkins.[24] More than anyone would say, Jesus himself called himself a teacher (Matt. 23:8; Mark 14:14; Luke 22:11 and John 13:13-14). Jesus was truly a perfect teacher, both divine and human.[25] In the Old Testament, it was generally the boys who became the students. Not so in the New Testament, Jesus taught a crowd of men or women; both in the synagogue, and in public spaces i.e. in the fields, on the hills, also on the lake with various patterns, including lectures,[26] memorization, dialogue, case studies, parables.[27] The Master's creativity and skill in teaching is shown when $\mathrm{He}$ uses local contexts to explain abstract spiritual matters.[28]

In His teaching, Jesus taught about the Kingdom of God, Himself and the future.[29] Jack Saymour states that if Christian education is to enrich today's congregations, it is necessary to pay attention to the way Jesus taught.[30]

Christian Education in the Era of the Church Fathers Different eras have different conditions behind religious education. The implementation of religious education in the Jewish era occurred because of the people's awareness of the need to return to obedience to God. Whereas what happened in this era, the ancient church was faced with four challenges[31] namely the culture of the gods; the church was challenged to find ways to make use of the intellectual fruit of the Greeks and Romans without expropriating its contents contrary to the Bible; the church was challenged to clarify its creed in the midst of the religious and 
intellectual currents known in GreekRoman times; and faced with various accusations that weakened their faith, that they were accused of being godless because in their worship there were no idols.

In the conditions faced by the ancient church, five great educators emerged, namely Clementus (150-215 AD), Origen (185-224 AD), Jerome (345-420 AD), Chrysostom (347-407 AD), Augustine (354-430 AD). Where each has its own pedagogical principles. According to Clementus, the teacher who plays the most important role in Christian religious education is not someone who stands in front of the class, but Jesus the word of God.[32] Origen, a disciple of Clementus, had a pedagogical principle, namely that the ability of human thinking was limited, therefore he needed revelation from God through the Bible and Jesus Christ. He developed an allegorical interpretation method because with this method he could reveal the hidden meaning in the passage.[33] In contrast to the previous two pedagogues, Hieronimus stated that the responsible teacher would choose the curriculum according to the needs of the students. The pedagogical principle that is still very relevant is to teach students something that cannot be rejected in the future, and the need to providerewards to students appropriately and avoid punishment which is not wise.[34]

The pedagogical principle of Chrisostomos requires parents to educate their children from a young age to act politely and respect all life, especially spiritual ones. In telling Bible stories to students, it is necessary to consider age to be relevant.[35]

While Aurelius Augustinus gave his pedagogical principle, namely the teaching style of a teacher needs to be adapted to the unique nature of each student and the need to apply the dialogue method in teaching.[36]

In the Reformation era, the reformers, their role in Christian education was in returning the main teachings to the Bible, as text book. Their other roles include publishing handbooks. They also pioneered the establishment of official Christian schools. Martin Luther, for example, he developed the curriculum, in addition to the Bible courses are: language, rhetoric, logic, literature, literature, history. During the Reformation period and after, as Martin Luther and John Calvin did, it brought about a change in modern Christian education in the sense of being open to research in the social sciences and reasoning.[37]

Through his writings Martin Luther 
sought to reform education and the teachings of the Reformation[38] and in his letter sent in 1524 to the Councilors of all the cities in Germany which organized Christian schools was evidence of his serious concern for Christian education.[39]

Not limited to the scope of the school, Luther also reformed education in the church, which he called the responsibility of the preacher, therefore the preacher must have good academic and oratory abilities.[40] According to him, educational activities should be centered on reading, writing and studying the Bible rather than classical books because the Bible is a source truth.[41] For Luther, the goal of Christian education is to protect and develop the people's personality, therefore teaching must be a top priority, taught by responsible and exemplary educators.[42]

In the field of education, Calvin's approach accepts contemporary educational theories and methodologies, but the aims of education must remain in accordance with the objectives of the code of conduct of the Scriptures, namely matters concerning the divine character and discipline of Christian life.[43]

Christian Education in the Industrial Revolution 4.0 The industrial revolution occurred four times. The first occurred in England in 1784 where the invention of the steam engine and mechanization began to replace human work. The second revolution occurred at the end of the 19th century in which production machines powered by electricity were used for mass production activities. Furthermore, the third revolution was marked by the use of computer technology for manufacturing automation starting in 1970. And now we are in the fourth industrial revolution, known as Industry 4.0. Industry Terms

4.0 itself was officially born in Germany precisely when it was held Hanover Fair in 2011. Various opinions define Industry 4.0, among others, Merkel argues that Industry 4.0 is a comprehensive transformation of various aspects.[44] Kagermann defines Industry 4.0 as the integration of Cyber Physical System (CPS) and Internet of Things and Services (IoT and IoS) into industrial processes including manufacturing and logistics and other processes. CPS is a technology that combines the real world with the virtual world.[45] The Industrial Revolution 4.0 is indeed a challenge but also brings many positive opportunities that offer many benefits.

This era marked by the sophistication of information technology raises hopes and worries that have an impact on changes in communication that change human relations,[46] and influencing relationships 
in evangelism.[47] Responding to this era, Iswarahadi emphasized the need to respond positively while using it wisely for preaching the gospel.[48] DW Lee, stated that this era should be seen as a facility and infrastructure permitted by God that must be used for preaching the word.[49] Kristianto emphasized the same thing that educators need to use these facilities to develop strategies for Christian religious education.[50]

Aryanto Budiono, in his article Word Teaching Innovation in the 4.0 Industrial Revolution Era[51] provide several solutions to address the industrial era 4.0 in conveying the word, namely through Live Streaming, Youtube as well as through various social media such as facebook, Instagram, WhatsApp, Twitter.

\section{CONCLUSION}

Through the study of Christian education (religion) which was carried out during the Old Testament and New Testament times, as well as in the era of the church fathers, a picture of the pattern of educational practice was obtained, that is, even though the underlying situations and conditions were different from one era to another, there were nevertheless one thing in common, that is, God has appointed His chosen people to convey his heart.

History also proves that in different eras and different environmental conditions from one era to another, Christian education was served creatively by people who were appointed by Him as the embodiment of the implementation of the divine mandate. Next, about how to deal with the Industrial Revolution 4.0? Several writers, as already described, agreed to emphasize that this era marked by various changes must be faced positively and creatively in order to serve Christian education which is basically an inseparable part of the Great Commission of Christ.

\section{REFERENCE}

[1] Ali Saifullah, Antara Filsafat dan Pendidikan: Pengantar Filsafat Pendidikan (Surabaya: Usaha

Nasional, $\mathrm{tt}$ ),

[2] Soelaiman Yoesoef, Konsep Dasar Luar Sekolah (Jakarta: Bumi Aksara, 1992) [3] Robert R. Boehlke, Sejarah Perkembangan Pikiran dan Praktek Pendidikan Agama Kristen dari

Yohanes Amos Comenius sampai perkembangan PAK di Indonesia (Jakarta: BPK Gunung Mulia, 2003),

[4] Robert R. Boehlke, Sejarah Perkembangan Pikiran dan Praktek Pendidikan Agama Kristen dari

Yohanes Amos Comenius sampai perkembangan PAK di Indonesia (Jakarta: 
BPK Gunung Mulia, 2003),

[5] Stepen Tong, Teologi Penginjilan (Surabaya, Momentum, 2004)

[6] Jim Petersen dan Mike Shamy, Menjadi Garam dan Terang Bagi Kalangan Terdekat (Bandung: Pionir

Jaya, 2007)

[7] Buletin Terang Lintas Budaya, Edisi 37 (Malang: Yayasan Terang Lintas, 2000)

[8] Homroghausen dan I.H Enklaar, Pendidikan Agama Kristen (Jakarta: BPK Gunung Mulia, 2015)

[9] Norman E. Harper, Making disciples (Memphis, Tennessee: Christian Studies Center, 1981)

[10] Paulus Lilik Kristianto, Prinsip dan Praktik PAK penuntun bagi Mahasiswa Teologi dan PAK,

pelayan Gereja, Guru Agama dan Keluarga Kristen (Yogyakarta: Andi Offset, 2008)

[11] Paulus Lilik Kristianto, Prinsip dan Praktik PAK penuntun bagi Mahasiswa Teologi dan PAK,

pelayan Gereja, Guru Agama dan Keluarga Kristen (Yogyakarta: Andi Offset, 2008)

[12] Eli Tanya, Gereja dan Pendidikan Kristen: Mencermati Peranan Pedagogis Gereja (Jakarta: STT

Cipanas, 1999)

[13] Johanes Oentoro, Industri Pendidikan di Milenial Ketiga (Tangerang: UPH Press, 2011)

[14] Gangel, Kenneth O. \& Benson, Warren S., Christian Education: Its History \& Philosophy (Moody

Press, 1983), 13.

[15] Harianto GP, Teologi PAK (Yogyakarta: ANDI, 2017), 387.

[17] Robert W, Pazmino, Pondasi Pendidikan Kristen (Bandung: STT Bandung, 2012)

[18] Robet R. Boehlke, .

[19] Robert R. Boehlke, Sejarah Perkembangan Pikiran \& Praktek Pendidikan Agama Kristen. Volume

1 (Jakarta: BPK Gunung Mulia, 2018)

[20] Robert W. Pazmino, Pondasi Pendidikan Kristen (Bandung: STT Bandung, 2012)

[21] Robert R. Boehlke.

[22] Albertus Purnomo, "Pendidikan sebagai Cara Hidup: Bercermin dari Rabi Yesus dari Nazaret" dalam Josephus, Against Apion, Book I., Sec. 12; Book II., Sec.

[23] Robert R. Boehlke, 70.

[24] Daniel Stefanus, Sejarah PAK (Bandung: Bina Media Informasi, 2009), 7. [25] J.M. Price, Jesus The Teacher (Bandung: Generasi Info Media, 2008), 48 [26] J.M. Nainggolan, Guru Agama Kristen Sebagai Panggilan dan Profesi: Suatu Upaya Peningkatan 
Journal Didaskalia

E-ISSN: 2621-8054

P-ISSN: 2622-1667

Mutu dan Kualitas Guru Agama Kristen

(Bandung: Bina Media Informasi, 2010)

[27] Robert R. Boehlke, Sejarah

Perkembangan Pikiran \& Praktek

Pendidikan Agama Kristen. Buku 1.

(Jakarta: BPK Gunung Mulia, 2018)

[28] Socratez, Yesus Sang Guru Agung

(Bandung: Kalam Hidup, 2018)

[29] Daniel Stefanus, Sejarah PAK

(Bandung: Bina Media Informasi, 2009)

[30] Jack Seymour, Teaching the Way of Jesus: Educating Christians for Faithful

Living (Nashville: Abingdon Press, 2014)

[31] Daniel Stefanus, Sejarah PAK

(Bandung: Bina Media Informasi, 2009)

[32] Daniel Stefanus, Sejarah PAK

(Bandung: Bina Media Informasi, 2009)

[33] Daniel Stefanus, Sejarah PAK

(Bandung: Bina Media Informasi, 2009)

[34] Daniel Stefanus, Sejarah PAK

(Bandung: Bina Media Informasi, 2009)

[35] Daniel Stefanus, Sejarah PAK

(Bandung: Bina Media Informasi, 2009)

[36] Robert R. Boehlke

[37] Anthony, Michael J. \& Warren S.

Benson. Exploring the History \&

Philosophy of Christian

Education: Principles for the 21st Century

(Grand Rapids, Michigan: Kregel

Academic \& Professional, 2003)

[38] R. Faber, Martin Luther on Reformed

Education (Clarion: The Canadian

Reformed Magazine Volume 47 No. 16
August 7, 1998: 376.

[39] R. Faber, Martin Luther on Reformed Education (Clarion: The Canadian Reformed Magazine Volume 47 No. 16 August 7, 1998: 376.

[40] Mihai Androne, The Influence of the Protestant Reformation on Education (Procedia: Social and Behavioral Sciences, 2014)

[41] Kenneth O. Gangel and Warrens S. Benson. Christian Education: Its History and Philosophy (West

Broadway: Wipf and Stock Publishers, 2002), 138.

[42] Matshiga, DJ. 2006. The Historical Development of Christian Education. https://repository.up.ac.za/bitstream/handl e/2263/ 30107/02chapters5-9.pdf:

[43] Alifius Areng Mutak, Reformasi dan Pendidikan Kristen: Menelusuri Warisan Reformasi dalam Pendidikan Kristen (Lawang: Jurnal Theologia Aletheia Vol.19 No.13 September 2017), 110.

[44] Merkel, A. (2014). Speech by Federal Chancellor Angela Merkel to the OECD Conference.https://www.bundesregierung. de/Content/EN/Reden/ 2014/2014-02-19oecd-merkel-paris_en.html

[45] Johanes Oentoro, Industri Pendidikan di Milenial Ketiga (Tangerang: UPH Press, 2011), 46-47.

[46] Naisbitt John, "Global Paradox" dalam Yewangoe A. A, (ed.). “Tantangan 
Journal Didaskalia

E-ISSN: 2621-8054

P-ISSN: 2622-1667

Gereja Memasuki Abad ke XXI" (Jakarta:

BPK Gunung Mulia, 1997), 51.

[47] Handreas Hartono,

"Mengaktualisasikan Amanat Agung

Matius 28:19-20 Dalam Konteks Era

Digital,” Jurnal KURIOS Vol. 4 No.2

(2018): , www.sttpb.ac.id/e-

journal/index.php/kurios.

[48] Iswarahadi I. Y, "Beriman dan

Bermedia Antologi Komunikasi"

(Yogyakarta: Kanisius, 2003)

[49] D.W. Lee. Khotbah Ekspositori yang

Membangunkan Pendengar: Krisis dan

Kesempatan Mimbar

Masa Kini (Bandung: Lembaga Literatus

Babtis 2000)

[50] Kristianto Paulus Eko, "Menjadi

Homo Informaticus: Pendidikan Agama

Kristen Untuk Remaja Di

Era Kecerdasan Buatan.,," In Membangun

Indonesia Di Era Revolusi Industri 4.0

(Jakarta: Universitas Kristen

Indonesia, 2018)

[51] Aryanto Budiono, Inovasi Pengajaran

Firman di Era Revolusi Industri 4.0.

PRUDENTIA Jurnal

Teologi dan Pendidikan Kristiani, Volume

1 No2, Desember 2018 (124-134) 